\title{
INTERCULTURAL JUSTICE. CUTTING ACROSS THE CULTURAL BOUNDARIES OF LEGAL NORMS
}

\author{
Francisco Colom González \\ Spanish National Research Council (C.S.I.C.)
}

\section{THE LIMITS OF MORAL CONSTRUCTIVISM.}

John Rawls' work on the theory of justice is considered to be largely responsible for the revival of political philosophy in the English-speaking world. His philosophical method, which he labelled moral constructivism, basically established a suitable connection between a particular conception of the person as a rational agent and a series of principles of justice which are agreed upon by means of a procedure of public reasonable deliberation (Rawls 1980: 516). Rawls' purpose was not to identify the ideas of justice held by a recognisable social group, nor to extricate the roots of moral reasoning and motivation, but rather to establish a set of valid and defensible criteria about justice. The subsequent philosophical debate in the North-American academia between the so called liberals and communitarians developed as a disagreement on the logic of moral foundation and on the ontological priority between the ideas of the good and the right. The question was not the freedom of the individuals to determine and pursue their moral goals, but the shared meanings that confer sense to a given set of social norms and to human action in general.

The discussion on multiculturalism and on the moral duty to recognize the differences which are deemed central to the dignity of the person relied on the same basic terms as the liberal-communitarian debate, but it introduced a new element, namely the consideration of culture as a condition of possibility for moral agency. By replicating the old Hegelian critique of Kantian philosophy, communitarians and multiculturalists emphasized the experiences provided by socialisation within concrete and stable cultural structures as a prerequisite for 
fundación

Manuel Giménez Abad

deEstudiosParlamentariosydelEstado Autonómico

the individuals to develop the judgement and autonomy needed to become responsible moral agents. Submitting our identity references to moral scrutiny is very different though from allocating goods and opportunities. Many goods are obviously not of a distributive kind, for they are not expendable, but that does not make them normatively less sensitive to the effects of distribution. This is typically the case of the conflicts and interests related to identity, like discrimination, marginalization, prejudice, etc. A broad current in contemporary philosophy has tried to apply the idea of justice to such issues from the Hegelian perspective of the moral recognition, but its derivations can also be perceived in other realms, like those dealing with memory, historical reparation and moral damage in general (Taylor 1992, Honneth 1994) ${ }^{1}$. In these cases the concern is with the moral and material restoration of injured dignity, not with the allocation of goods.

Even if the liberal-communitarian debate took place mainly within the borders of political philosophy, we can easily recognise the relevance of some of its topics for other fields. The communitarian conviction that the principles of justice must count on the compliance of those involved in them and that moral injures can to some extent be healed, opens up the possibility to explore the cultural boundaries of justice. This is a task for which moral constructivism and legal positivism are not well suited. Both perspectives refuse to consider social ways of life as a source of normative authority. They also share a hierarchical conception of the systems of norms, either understood as a qualitative gradation of possible consensus -from a constitutional one to a mere modus vivendi- or by distinguishing between primary and secondary rules (Rawls 1993; Hart 1961). On the contrary, if we admit that the legal order is in fact the political and juridical systematization of living moral practices and that justice is not an abstract code of legal statements, but what entitled legal practitioners perform, we will be able to recognize the polycentric character of many legal systems and the uneven scale of their normative efficacy. This leads to the main problem of legal pluralism, namely the interpretation of norms across the boundaries of different moral and legal systems.

\footnotetext{
${ }^{1}$ For the realm of memory and reconciliation with the past, see also the idea of anamnetic justice developed by Mate 1991.
} 


\section{LIVING LAWS.}

Legal pluralism can be understood either as a social fact or as a stream of thought in contemporary legal theory. In the first sense it simply refers to the inexistence of a unified and homogeneous legal source in a given society, be it for the political inability of the state to impose it -as is the case in many Third World countries where aboriginal customary law coexists with positive law- or for the organized coexistence of two or more legal systems -as for instance in Canada, where English common law and French civil law have been preserved on a territorial basis. As a theoretical approach, legal pluralism takes into account the parallel and often contradictory types of legitimation beneath existing legal norms. The epistemological tenets of legal pluralism are remarkably close to those of philosophical communitarianism (Petersen - Zahle 1995; Sheleff 2000). Eugen Ehrlich, one of the founders of legal sociology and witness to the inextricable diversity of the Habsburg Empire, introduced the concept of living law (lebendes Recht) in order to criticize the approach of traditional jurisprudence for only studying the written laws laid down in the Austrian legal code and ignoring the richness of legal traditions beneath it. As he tried to show in his empirical work on the legal customs regulating marriage and inheritance in his native Bukovina region, for most people legal obligation is induced by social norms of behaviour rather than by an abstract abidance to the law $^{2}$. To gain a historical understanding of a legal system, the hermeneutic duty of the jurist is to search for the roots of present laws in the laws of the past. The study of communitarian forms of conflict resolution in contemporary legal anthropology has come to similar conclusions, namely that the stability of the agreements reached in this way increases when they originate in a context of shared values and common social experiences (Depew 1996).

If we try to bring the empirical evidence of legal pluralism to philosophical consideration, the moral hermeneutics developed by Michael Walzer with his idea of the spheres of justice, becomes a useful heuristic tool (Walzer 1983). As

\footnotetext{
2 "The rules that, by themselves, people living together consider binding, are the living law. They constitute a legal order just like those included in legal codes. The difference is that the former become valid by the voluntary action of the parties involved, whereas the latter must, to a great extent, be enforced by the courts and public authority". (Ehrlich 1986: 233)
} 
fundación

Manuel Giménez Abad

deEstudios ParlamentariosydelEstado Autonómico

is known, Walzer discards the notion of universal principles of justice. He relies instead on the interpretation of the institutions and practices of a given society and on the beliefs that its members have about them. Justice is therefore understood as a social construct locally produced within a certain period of time. The effectiveness of a scheme of justice depends on a set of common understandings without which the adjudication of goods is unintelligible or will be perceived as arbitrary by their recipients. This is altogether practical evidence: the attempt to apply principles of justice that are alien to the lifeworld in which they must operate turns them sterile and unable to perform the regulative functions that are expected from them. But Walzer goes further when he asserts the heterogeneity of the social goods and the inherent relationship between their meaning and the regulative principles on which they depend. Love, Godly grace and social recognition would be drastic examples of the conceptual connectedness linking goods and principles, for their distribution following standards that are alien to them, like money or power, would be an oxymoron. In other cases Walzer comes to accept that the link between social goods and regulative principles is not a conceptual but a contingent one: in some societies certain goods are predominantly associated with particular distributive criteria. Following his own terminology, the normative realm defined by each kind of good constitutes a sphere of justice.

Walzer's approach is therefore pluralistic in both normative and epistemological terms: justice is what the members of a given community consider to be fair. To criticise the principles of justice of a community from outside is incoherent and inadequate, for justice only has meaning within a frame of shared understandings. On the other hand, the invasion of a sphere of justice with principles belonging to a different sphere would be a moral contravention. This explains why some reparations augment the injury of those who receive them or why some criteria of justice are perceived as unfair or unintelligible when they transcend the historical and cultural contexts within which they originated.

Walzer's assumptions have been widely criticised. The critiques have mainly focused on the close link that he establishes between social goods and regulative principles and on his identification of the moral and the political 
fundación

Manuel Giménez Abad

deEstudiosParlamentariosydelEstado Autonómico

community, when there is in fact a wide range of moral criteria shared by persons who do not belong to the same polity. In any case, our interest in Walzer is merely instrumental. The main problem with his approach is that it offers no explanation on the dynamics of shared social meanings and falls into the inescapable debate between moral relativists and objectivists. What Michael Walzer calls spheres of justice is not only defined by the character of the social goods and their specific regulative criteria, but first and foremost by the social and cultural contexts in which they are applied.

The claims for the cultural and political recognition of social minorities are nowadays stronger than ever. The naïve and blind universalism envisioned by the Enlightenment has given place to new forms of moral particularism which are advocated in terms of social fairness and compensation for past abuses. Aboriginal movements, for instance, are reminding us of the compulsory process of acculturation to which their peoples were submitted and whose legitimacy relied on the purported benefits that membership in a national society and the acquisition of citizenship rights would bring to their members. This process often resulted in the social and cultural disintegration of native communities and in several forms of anomic behaviour. This example calls for an explanation as to how moral learning and exchange across cultural boundaries is possible and why the relationship between subjects and culture is not a contingent or fortuitous one.

Individuals develop their moral judgment, self-esteem and identity by competently exercising their social capabilities within a network of shared cultural meanings. Moral and social competences presuppose a familiarity with the symbols, norms and values that define a boundary of social action. The relation between norms, cultural meanings and moral competence points us to the regulatory function of normative systems in general and to consider the possibility of cultural equivalences in their performance. We cannot assume that all normative systems are naturally compatible or that they fulfil exactly the same functions, but we must recognise that all of them have to respond to certain regulative inputs, especially to those concerning matters of distributive and compensatory justice. 
fundación

Manuel Giménez Abad

deEstudios ParlamentariosydelEstado Autonómico

The experiences of legal pluralism as they have been driven by some cultural minorities offer a practical example of the political and normative dilemmas they involve. The increasing strength of aboriginal movements throughout the Americas, from Chile to Canada, has little to do with the revival of ancestral voices and much more with the ethnogenetic processes and the new forms of social mobilisation induced by the present global stage of modernization. In less than two decades these movements have become organized and have emerged on the global arena as new and legitimised political actors. This is particularly obvious if we consider the evolution of international law and the use that aboriginal peoples make of the language of rights to frame their claims. There is thus a considerable normative distance between the abstract individualism of the Universal Declaration of Human Rights from 1948 and the right to collective self-determination and cultural survival mentioned in the Draft Declaration on the Rights of Indigenous Peoples, which is waiting to be passed by the United Nations since $1994^{3}$. On the other hand, during the last years native movements have become main actors of constitutional reform in Mexico, have bargained devolution policies in Canada and have been able to bring down governments in Bolivia.

More relevant to our interests here are their achievements in the legal realm and the normative problems that they present. Nowadays Canada and the majority of the Latin American countries constitutionally have recognized the pluriethnic and multicultural character of their societies (Van Cott 2000; Cairns 2000). Such recognition has resulted in the consolidation of several forms of legal pluralism that reflect what in many cases was a social fact: the survival of customary law and traditional procedures of conflict resolution in many indigenous communities. In Latin America the movement in favour of aboriginal justice has usually been pressed by the desire of native peoples to exercise a closer control on local disputes and in order to compensate what is perceived as state negligence in the management of their internal affairs. The issue in Canada is not so much the political competence of the state as it is the internal

\footnotetext{
${ }^{3}$ There are other relevant international documents, like the Convention 169 of the International Labour Organization on Indigenous and Tribal Peoples in Independent Countries (1989) and the Declaration on the Rights of Individuals belonging to National, Ethnic, Religious or Linguistic Minorities (1992). For a global approach on the issue, see Thornberry 2002.
} 
decolonisation, the overcoming of the social and economic marginalization that haunts native communities and the wave of aboriginal nationalism that has risen since the patriation of the Constitution in $1982^{4}$. It must be also added that native peoples have not been the only ones to push for the introduction of legal pluralism in the Canadian judicial system. The multicultural tenets of the Charter of Rights and Freedoms have also been used by some religious groups to press for faith-based arbitration boards. In the Anglophone provinces there was since the nineteenth century the possibility of private religious arbitration, Christian and Jewish, in family matters. In October 2003 a local religious lobby, the Islamic Institute of Civil Justice, declared its purpose to create a Sharia court in Ontario that would apply on a voluntary basis the traditional Islamic law in marriage and other private disputes within the Muslim community. As a reaction to the public concern expressed in the media, in June 2004 the Ontario Attorney General asked Marion Boyd, an independent legal consultant, to conduct a review of the use of arbitration. The worry was that this device became a judicial ghetto for the most vulnerable members of society, mainly women who had recently migrated into the country and marginalized ethno-religious groups. The report produced for the provincial authority recognised that "Canada is a multicultural society and the fundamental tension that must be addressed is between respect for the minority group and protection of a person's individual rights within that minority", but it did not exclude the possibility of arbitration using religious law in family and inheritance cases, provided that the promotion of alternative ways of dispute resolution for minority groups was balanced against "a firm commitment to individual autonomy" (Boyd 2004). The Ontario Parliament -and the Quebec National Assembly soon thereafter- nevertheless voted against the maintenance or the introduction of religious arbitration.

\footnotetext{
${ }^{4}$ The situation of native peoples in Canada was thoroughly studied by a Royal Commission on Aboriginal Peoples, which issued its Report in 1996. The Report recommended initiating a new relationship between Canada and the native peoples based on their recognition as autonomous nations with a unique place in the country (Canada 1996).
} 


\section{INTERPRETING TRADITION.}

The case for aboriginal law is much more advanced at the national and international levels. The legal autonomy of aboriginal peoples was recognized by the Convention No. 169 of the International Labour Organization (I.L.O. 1989). Article 8.2 of the Convention declares that indigenous peoples must have "the right to retain their own customs and institutions, where these are not incompatible with fundamental rights defined by the national legal system and with internationally recognised human rights". Article 9.1 goes further to stipulate that whenever such compatibility is assumed, the procedures traditionally used by the indigenous peoples to sanction the offences committed by their members should be respected. In most cases, however, the conciliation between positive law and aboriginal customary law has not been fully achieved. The rejection of the principle of self-determination and the mistrust of collective rights are some of the reasons why the UN Draft Declaration on the Rights of Indigenous Peoples has not been passed yet. But at the local level there are also problems of compatibility between the indigenous jurisdictions and the individual human rights enshrined in national constitutions.

We have to bear in mind that aboriginal law is essentially constituted of a series of customs socially endorsed within a given community. It usually works like an arbitration procedure administered by the local political authorities. In the Andean area of Latin America the judicial authority is typically the Cabildo or indigenous council (a local institution stemming from the colonial times), which deliberates in an open assembly. In the Amazon region native authority is represented by the curaca or cacique (chief). In Canada minor offences are sometimes tried on a voluntary basis through sentencing circles, in which a professional judge is assisted by members of the community in finding the proper sanction for the offender. In some African countries, like Gabon, we can also find neighbourhood chiefs (chefs du quartier) who administer justice according to the traditional laws of their circumscription (Bé-Nkogho Bé 2006) ${ }^{5}$.

\footnotetext{
${ }^{5}$ In this case, indigenous justice stems from the system of tribunaux coutumiers set up by French colonial authorities to deal with native litigation. As was recognized in Article 75 of the Government Decree of November 10th, 1903, "the indigenous justice [la justice indigène] will
} 
fundación

Manuel Giménez Abad

deEstudios ParlamentariosydelEstado Autonómico

The issue is that in traditional communities there is a predominantly organic understanding of the common life. The consequences of personal actions are therefore not perceived in strictly individualistic terms, but as involved in an extended network of family connections. Even more important is the fact that juridical customs are not formally differentiated from the social structure of the group, but enmeshed into it. Binding norms respond to what has been labelled a compensatory or conciliatory model of social control. It is a material law built upon substantive assumptions about the character of the community and it basically seeks to re-establish what is perceived as harmony among its members. Guilt is therefore not as important as restoring the harm done. The procedures are usually oral and priority is given to achieving a rapid and exemplary sanction, which usually consists of a pecuniary fine, compulsory communal work, corporal punishment or several forms of ostracism.

However, the problems of compatibility between native customary law and positive law are many and serious. Very often they have to do with jurisdictional boundaries, particularly when the offenders are not aboriginal or the offence took place outside of the community, for there is a tendency among the native peoples to interpret their jurisdiction as an ethnic attribute and not strictly in terms of political self-government. This is particularly true in Latin America. Whereas in places like Ecuador aboriginal justice is trying to displace positive law and to prevent the access of natives to the national legal system (García 2002), there are countries, like Canada or Colombia, in which an interesting jurisprudence has developed in order to conciliate both legal spheres (Green 1998; Arbeláez 2004). I will here refer to a couple of significant examples. The sentence T-349/1996 of the Supreme Court of Colombia tried to establish the limits of the aboriginal jurisdiction in the country (Gaviria Díaz 2002). It dealt with an appeal against the General Assembly of Indigenous Councils (Cabildos) and the United Major Council of the Risaralda region by a native of the EmberaChamí group who had been accused of murder in his community. He had been tried, while in absence, by means of the procedure of customary law and was condemned to twenty years in a white prison. The plaintiff asked for the

apply local customs in all matters, as far as they are not contradictory with the principles of French civilisation. When physical punishment is involved, it will be replaced by imprisonment". 
fundación

Manuel Giménez Abad

deEstudiosParlamentariosydelEstado Autonómico

protection of the Court considering that his constitutional rights to due process, to legal defence, to life and to physical integrity had been encroached. In the consideration of the constitutional principles that protect cultural diversity and individual rights, the magistrate who issued the sentence chose to apply a version of the maximin rule: to maximize the autonomy of the indigenous communities and to minimize the restrictions to it down to the point where they are deemed indispensable for the safeguard of interests of a higher hierarchy. Such interests were identified by the judge as the right to life, the prohibition of slavery and torture and the preservation of due process, since "it is only about them that we can presume the existence of a real intercultural consensus" (Gaviria Díaz 2002: 355).

What is interesting about this sentence is the effort to search for equivalence in the customary law for the juridical goods protected by positive law. According to the Colombian magistrate, the notion of due process, which is alien to the Embera-Chamí mentality, has an equivalent in the community's rejection of arbitrary authority and in the obligation of aboriginal authorities to behave as they had done in the past, namely by referring to the established traditions. The same can be said about the right to legal defence, since the offender, although being absent, had his interests represented by his relatives. It must be pointed out that two magistrates of the Court Committee declared in their vote of dissent that the plaintiff's right to an adequate defence had not been sufficiently guaranteed. In fact the Court accepted the part of the demand concerning the legality of the punishment applied to him and urged the General Assembly of Indigenous Councils to try him again according to their traditions or to remit him to the ordinary judicial system. But the Colombian Supreme Court was able to recognize some of the goods contained in aboriginal customary law, even if criminal law does not assume the preservation of collective identity or the restoration of a substantive social order among its objectives.

An opposite example of normative translation across cultural boundaries can be found in some contemporary currents of Islamic feminism. This is basically an intellectual movement with a modern discourse about women's rights and with 
some ramifications in militant groups like Sisters in Islam ${ }^{6}$. Like many other reform movements in modern Islam, the innovative efforts of Islamic feminism run through the core of its cultural tradition and make use of what is its typical tool: the interpretation of the sacred texts. The reason for this is that even if Islamic religion relies on a revealed text, the Koran mainly contains principles, not the details on how to develop them in a way of life. Islamic feminists have therefore had to fight on two fronts: against gender biased interpretations of the Koran and against what many of them consider as a neo-colonial discourse by Western feminists, who understandably are not ready to see any emancipator potential in a religion that, at least in its conventional version, reinforces gender inequality (Moghissi 1999; Fernea 1998).

The main objective of this movement is thus to reinterpret the sacred texts and to participate in an ideological process that has been traditionally reserved for men. Its militants understand their feminism as an inherent part of their religious commitment, to which they wish to incorporate their own personal experiences as women. In order to articulate this double vocation they rely on the critique of established Islamic epistemology and on a particular combination of traditional hermeneutic instruments (like the tafsir, explanation and commentary of the Koran, and the ijtihad, a normative reasoning based on the autonomous interpretation of legal sources), and post-modern techniques (linguistics, deconstructionism, historical analysis of texts). The basic idea is that the principle of gender equality is essentially contained in the koranic texts but has been subverted by the interpretative practices, which would rather reflect the personal interests of the narrators and the patriarchal prejudices of the societies to which they belonged. Classical jurisprudence and the interpretation of the hadith (the sayings and deeds attributed to the Prophet) would consolidate the prevalence of misogyny in the Sharia, the traditional Islamic law (Mernissi 2003). This is then the peculiar case of a movement that advocates typically modern principles (like gender equality) and makes use of sophisticated hermeneutic instruments with a post-modern purpose (the deconstruction of

\footnotetext{
${ }^{6}$ The self-declared mission of Sisters in Islam is "to promote an awareness of the true principles of Islam, principles that enshrine the concept of equality between women and men, and to strive towards creating a society that upholds the Islamic principles of equality, justice, freedom and dignity within a democratic state". Sisters in Islam, http://www.sistersinislam.org.my/
} 
fundación

Manuel Giménez Abad

deEstudios ParlamentariosydelEstado Autonómico

Islamic patriarchalism) in order to reaffirm a traditionalist position: the role of Islamic texts as a source of moral authority.

The examples brought here into consideration, aboriginal customary law and Islamic feminism, raise the issue of the denaturation of legal norms; in this case, if it is possible to advocate modern normative intentions with languages and principles that are not strictly so $^{7}$. We need not consider the process of denaturation in negative terms, since it basically depicts the means in which tradition operates: by transferring social practices to new cultural environments and thereby changing their original meaning. In both of our cases we can recognise a background of universalistic values that can be formally assimilated to contemporary views on human rights: human dignity and due process in one case and gender equality in the other. They also reflect two different experiences of cultural adaptation and moral learning: modern positive law trying to read customary law, and religious traditionalism trying to advance egalitarian ideas. Such cases may help to conclude that universalistic values cannot anymore be taken for granted in a naïve way: they must gain their own legitimacy by showing that they can adapt to changing social circumstances and that they are able to accept moral interpellations stemming from other cultural environments. Obviously, this is not and will not be an easy process. On it depends though, that the agenda of late modernity can still stir the moral imagination of those who received it as an exogenous or imposed phenomenon -the so-called losers of modernity- and reacted with a programme opposing it.

\footnotetext{
${ }^{7}$ In anthropology, the French term dénaturation refers to the loss by a legal system of the characteristics that define its specificity against other systems, that is, the change of its fundamental logic so that "the legal system is dispossessed of what constitutes its identity, leaving the population with rules and habits that are in the process of losing their meaning" (J. R. Bé-Nkogho Bé 2006).
} 
fundación

Manuel Giménez Abad

deEstudiosParlamentariosydelEstado Autonómico

\section{BIBLIOGRAPHY}

- ARBELÁEZ DE TOBÓN, L., 2004, La Jurisdicción Especial Indígena en Colombia y los mecanismos de coordinación con el sistema judicial nacional, Consejo Superior de la Judicatura de Colombia, Agosto 11, 2004 http://www.dplf.org/AINDG/span/gt aindg04/gt aindg04 Tobon.pdf

- BE-NKOGHO BE, J. R., 2006, La persistance de la justice traditionnelle au Gabon: quelques réflexions, Ethno-web, http://www.ethnoweb.com/articles.php?action $=$ show $\&$ numart $=90$

- BOYD, M., 2004, Dispute Resolution in Family Law: Protecting Choice, Promoting Inclusion - Executive Summary, December 2004 http://www.attorneygeneral.jus.gov.on.ca/english/about/pubs/boyd/execut ivesummary.pdf

- CAIRNS, A., 2000, Citizens plus: aboriginal Peoples and the Canadian State, Vancouver, University of British Columbia Press

- Canada. Royal Commission on Aboriginal Peoples, 1996, Report of the Royal Commission on Aboriginal Peoples (5 Vols.), Ottawa, The Commission

- Depew, R. C., 1996, Popular justice and aboriginal communities. Some preliminary considerations, Journal of Legal Pluralism and Unofficial Law 36 (Special Issue: Popular Justice: Conflict Resolutions within Communities): 21-67

- EHRLICH, E., 1986, Gesetz und lebendes Recht. Vermischte kleinere Schriften, ed. by Manfred Rehbinder, Berlin, Duncker \& Humblot (Schriftenreihe zur Rechtssoziologie und Rechtstatsachenforschung; Bd. 61) 
fundación

Manuel Giménez Abad

deEstudios ParlamentariosydelEstado Autonómico

- FERNEA, E. W., 1998, In search of Islamic Feminism: one Woman's Global Journey, New York, Doubleday

- GARCÍA, F., 2002, Formas indígenas de administrar justicia. Estudios de caso de la nacionalidad quichua ecuatoriana, Quito, FLACSO

- GAVIRIA DÍAZ, C., 2002, Sentencia de Tutela T-349 de 1996, in: Sentencias. Herejías constitucionales, México, Fondo de Cultura Económica-Colombia: 351-367

- GREEN, R. G., 1998, Justice in Aboriginal Communities. Sentencing Alternatives, Saskatoon, Purich Publishers

- HART, H. L. A., 1961, The Concept of Law, Oxford, Clarendon Press

- HONNETH, A., 1994, Kampf um Anerkennung: zur moralischen Grammatik sozialer Konflikte, Frankfurt, Suhrkamp

- International Labour Organisation, 1989, Convention 169 concerning Indigenous and Tribal Peoples in Independent Countries,

- http://www.ilo.org/ilolex/cgi-lex/convde.pl?C169\#Link

- MATE, M. R., 1991, La razón de los vencidos. Barcelona, Anthropos

- MERNISSI, F., 2003, Beyond the Veil: male-female Dynamics in Modern Muslim World, London, Saqi Books

- MOGHISSi, H., 1999, Feminism and Islamic Fundamentalism: the Limits of Postmodern Analysis, London-New York, Zed Books

- PETERSEN, H. - Zahle, H., 1995, Legal Polycentricity: Consequences of Pluralism in Law. Darmouth, Aldershot 
fundación

Manuel Giménez Abad

deEstudiosParlamentariosydelEstado Autonómico

- RAWLS, J., 1980, Kantian Constructivism in Moral Theory, The Journal of Philosophy 77 (9): 515-572.

- RAWLS, J., 1993, Political Liberalism, New York, Columbia University Press

- SHELEFF, L., 2000, The Future of Tradition. Customary Law, Common Law and Legal Pluralism, London, Frank Cass

- TAYLOR, Ch., 1992, Sources of the Self. The Making of Modern Identity, Cambridge, Cambridge University Press

- THORNBERRY, P., 2002, Indigenous Peoples and Human Rights, Manchester, Manchester University Press

- WALZER, M., 1983, Spheres of Justice: a Defense of Pluralism and Equality, New York, Basic Books

- VAN COTT, D. L., 2000, The friendly liquidation of the past: the politics of diversity in Latin America, Pittsburgh, University of Pittsburgh Press 